\title{
The structure of the Asian debt crisis in theoretical and historical perspective
}

Citation for published version (APA):

Ziesemer, T. H. W. (1998). The structure of the Asian debt crisis in theoretical and historical perspective. MERIT, Maastricht Economic Research Institute on Innovation and Technology. MERIT Research Memoranda No. 009 https://doi.org/10.26481/umamer.1998009

Document status and date:

Published: 01/01/1998

DOI:

10.26481/umamer.1998009

Document Version:

Publisher's PDF, also known as Version of record

\section{Please check the document version of this publication:}

- A submitted manuscript is the version of the article upon submission and before peer-review. There can be important differences between the submitted version and the official published version of record.

People interested in the research are advised to contact the author for the final version of the publication, or visit the DOI to the publisher's website.

- The final author version and the galley proof are versions of the publication after peer review.

- The final published version features the final layout of the paper including the volume, issue and page numbers.

Link to publication

\footnotetext{
General rights rights.

- You may freely distribute the URL identifying the publication in the public portal. please follow below link for the End User Agreement:

www.umlib.nl/taverne-license

Take down policy

If you believe that this document breaches copyright please contact us at:

repository@maastrichtuniversity.nl

providing details and we will investigate your claim.
}

Copyright and moral rights for the publications made accessible in the public portal are retained by the authors and/or other copyright owners and it is a condition of accessing publications that users recognise and abide by the legal requirements associated with these

- Users may download and print one copy of any publication from the public portal for the purpose of private study or research.

- You may not further distribute the material or use it for any profit-making activity or commercial gain

If the publication is distributed under the terms of Article $25 \mathrm{fa}$ of the Dutch Copyright Act, indicated by the "Taverne" license above, 


\section{THE STRUCTURE OF THE ASIAN DEBT CRISIS IN THEORETICAL AND HISTORICAL PERSPECTIVE}

Thomas Ziesemer, Maastricht University, MERIT and Department of Economics, P.O.Box 616, NL - 6200 MD Maastricht; Phone: 31-43-3883872; fax: 31-43-3216518;email:[t.ziesemer@algec.unimaas.nl]. April 1998.Comments invited.

\section{Introduction:}

This paper has been provoked by a student who told me that the Asian debt crisis was quite different from the earlier debt crises after having read Krugman (1998a) . Having some knowledge about the earlier debt crises (see Ziesemer 1997a) and having followed the news on the Asian debt crisis I had more of a feeling 'deja vu'. In particular, I saw an outstanding role of the dollar revaluation which did beat those countries that had fixed exchange rates with the dollar: This time the Asian countries and not Latin America whereas it had been the other way around in the 1982 crisis, when the Asian countries had more flexible exchange rates than the Latins. Of course, many differences between Asia and Latin America are obvious, but is every thing really totally different?

In this paper we will try to find the similarities and differences between earlier crises and that in Asia. To understand the literature on the Asian debt crisis it is advantageous to have some knowledge on earlier debt crises and of the development of the Asian economies which we present in subsections 1.1 and 1.2. The structure of the rest of this article is as follows. In section 2 we consider the Asian debt crisis, starting with the summary of five rather controversial views in section 2.1 which differ mainly by the way how they emphasize microeconomic and institutional, macroeconomic, domestic and international fundamentals. From these we derive the topics on which the rest of this paper will concentrate. In section 2.2 we consider the various forms of financial excess and moral hazard on a country by country basis to get some more differentiation into the debate from the point of view of microeconomic and institutional fundamentals. In section 2.3 we discuss domestic fundamentals which have been declared irrelevant by Krugman but have the sole emphasis from Sachs. In section 2.4 we discuss the role of international fundamentals and the revaluation of the US dollar. This leads to the question whether or not fixed exchanged rates are a sustainable policy when the currency to which a country ties its own currency is revalued, which is discussed in section 2.5. Another controversial point to be discussed in section 2.6 is the issue of contagion. Once the crisis has occurred the question is what the causes and consequences of real devaluations are; we turn to that in section 2.7. In section 3 we discuss special questions which seem to be the source of many mis- and nonunderstandings. In section 3.1 we provokingly respond to the question 'why didn't anyone see the Asian crisis coming'. In section 3.2 we make some remarks on the question of the transmission of the crisis to Europe and the USA and we show how one can be misled by not differentiating between countries when discussing the crisis. In 3.3 we will discuss some aspects of IMF policy. In 3.4 we briefly deal with the question 'Is the Asian miracle over?'. Section 4 summarizes the major lessons and pitfalls and concludes. 


\subsection{A typology of debt crises: Theory and History}

A typology of debt crises can probably most easily constructed by beginning with a distinction between single country crises and world economic crises. Debt crises in connection with world economic crises were those of the 1930s and the 1982 crisis. For these crises it is typical that there is an increase in world market interest rates and a world recession which leads to a break down of investment and export demand. Export demand being crucial for the payment of imported capital goods this leads to a major recession and an inability to pay the debt service. It is clear that the current crisis in Asia is not a crisis accompanied by a world recession or high world market interest rates. The only things that is common to all countries currently is the development of the value of the US dollar, the yen and their own currency values as well as the slow growth of Japan. To this we return later.

Single country crises are typically viewed as foreign currency crises with speculative attacks. The standard story (see Krugman 1979) says that they occur when countries finance large government deficits with central bank money. The equilibrium exchange rate, if it were flexible would undergo a devaluation. However, if countries have fixed exchange rates which they try to keep unchanged, they have to sell foreign exchange reserves. The amount of foreign exchange reserves being limited it is clear that this can be done only for some time. Once reserves are down to zero the currency must be devalued. Domestic citizens knowing that will try to hedge and therefore sell domestic currencies and buy foreign exchange; foreign and domestic speculators knowing the same will take short positions in domestic currencies of the deficit country, buy foreign exchange denominated assets expecting their debt to be devalued and their assets to be revalued. Both these activities will speed up the depletion of foreign exchange reserves of the country in question and will make speculators rich if the devaluation is coming about. If there are no deficits the foreign exchange disequilibrium can come about because of changes in expectations. In addition the models have been broadened including a decision of the government to devalue in order to regain flexibility or to defend the exchange rate in order to preserve credibility of the fixed exchange rate (see Obstfeld 1994).

Moreover, one can easily imagine that a shock of world economic recessions with its increase in interest rates and the drop in exports also leads to overvaluations which can provoke the same problem (see Ziesemer 1997a, Chap. 5.1 for sketch of this idea). Finally, a permanent revaluation of Asian currencies in comparison to all other currencies except for the dollar, when they are tied to the dollar and the dollar rises over time (from April 1995 until the beginning 1998 because of foreign economic policy rather than domestic deficits), could also provoke overvaluations and speculative attacks. Although the last two examples have not yet been proven theoretically it is rather likely that it is possible to do so in the future.

A brief history of crises can be told as follows (see Ziesemer 1997a, Chap. 7 as a trace to the original literature). The crises in the 1930s, 1870s, 1890s happened to occur as byproducts of world business cycle downswings. Lack of export revenues make the debt service impossible. However, some of these crises also have their particular aspect, such as the drop in guano prices stemming from the introduction of new variants of fertilizer in Peru 1876 or the fact that debt service became due in 1890 in Argentina before the infrastructure investment for which the loans had been used yielded any returns (development default). However, in the 1890s most problems were domestically generated. In the 1930s the world wide recession with high interest rates and the induced protectionism reduced export demand. Prices of developing country exports often fell by 30 or $40 \%$. Obviously debt service 
payments become difficult then. For the 1982 crisis also high interest rates, a world economic recession with its negative effects on export demand and an increase in protectionism are the relevant element. Whereas it is debatable whether the interest shock was larger in the 1930s or 1982 , it is rather clear that the drop in exports was more severe for all countries in the 1930s. However, it is also clear that in the crises of 1930 and 1982 countries with less solid economic policy have been suffering earlier and more severely.

After the 1982 crisis there were several single country crises in Mexico. The one most lively debated is that of 1994/5. Some authors have characterized it as a typical foreign currency crisis. However, there are other explanations as well (see Journal of International Economics 1996). Obviously, it is too early to decide on the debate here.

The Asian crisis on the one hand is not part of a world economic crisis; on the other hand it is not a single country crisis. Although the latter view has some attractiveness because the problems in these countries are very much different from country to country, in particular the forms and extent of financial excess varying by country, there also must be something international that these countries have in common; some say it is moral hazard, corruption etc. whereas others say that it is the dollar revaluation. In this paper we shall introduce all the views but ultimately we will emphasize the common value of dollar, yuan and yen and the slow growth of Japan, which must at least explain why these countries came into trouble all at the same time in the same region.

\subsection{From Asian development policy success to the debt crises}

Recent empirical literature (see Young 1994; Collins and Bosworth 1996) has clearly confirmed the standard wisdom in development economics that the Asian success is due to increased inputs and not due to an outstanding performance in the enhancement of total factor productivity. Employment participation has been increased for man and women. People have received more education and the investment/GDP ratios have been outstandingly high. This can be summarized as in the scheme 1 and table 1 below. There is a clear ranking in the orders of magnitude in the growth rates of table 1: Obviously, the growth rate of the capital stock is the largest of all these growth rates being in the order of magnitude of $10 \%$. The second largest is that of manufacturing employment being in the order of magnitude of 5-9\%. The third in ranking is human capital growth in the order of magnitude $2-5 \%$. Finally, total factor productivity growth ranks lowest being in the order of magnitude 0-2\%. Another result of high capital accumulation besides high growth is also large debt.

Scheme 1. Factors of production, policies and results

\begin{tabular}{lll}
$\begin{array}{ll}\text { Production factor } \\
\text { physical capital }\end{array}$ & Policy & \multicolumn{1}{c}{ Results } \\
human capital & Savings and foreign debt & high capital growth, large debt \\
low skilled labour & Employment cum population policy & $\begin{array}{l}\text { Some high, some low } \\
\text { high employment, low popu }\end{array}$ \\
gechnology & R\&D & $\begin{array}{l}\text { TFP growth not higher than } \\
\text { OECD }\end{array}$
\end{tabular}


The interpretation of the data from the point of growth theory is also clear. If the longrun growth rate of a country is determined by its total factor productivity growth rate as neoclassical growth theory would postulate, and total factor productivity is growing no faster than OECD countries do, in the long run growth rates of the Asian countries considered in the tables must come down to those of the OECD countries. A slow down of growth towards its natural rate (to be corrected for income and price elasticities of export demand see Ziesemer 1998) is a natural prediction - Krugman made it.

\section{Table 1. Growth rates of factors of production and total factor productivity}

$\begin{array}{lccccc}\begin{array}{l}\text { Country } \\ \text { Variable }\end{array} & \text { Korea } & \text { Indonesia } & \text { Thailand } & \text { Malaysia } & \text { Taiwan } \\ \text { TFPGR }^{\mathrm{a}} & 1.4 & 0 & 1.9 & 1.0 & 1.5 \\ \mathrm{KGR}^{\mathrm{b}} & 12.6 & 8.3 & 10.6 & 10 & 12.2 \\ \mathrm{HGR}^{\mathrm{c}} & 3.3 & 4.5 & 2.3 & 3.3 & 2.8 \\ \mathrm{LGR}^{\mathrm{d}} & 5.5 & 8.9^{\mathrm{e}} & 5.1 & 8.2^{\mathrm{e}} & 5.6\end{array}$

a Annual total factor productivity growth 1970-1985; source: Young 1994;

b Capital stock growth rate average 1960-94; source: Collins and Bosworth 1996.

c Average years of schooling, growth rate 1960-94; source: Collins and Bosworth 1996.

d Manufacturing employment annual growth 1970-90; source: Young 1994 unless otherwise indicated.

e UNIDO Industrial Statistics Data Base.

An obvious problem with such a prediction is that firms need an expectations adjustment towards growth rates of 1-2\% from very high ones and they need to know when it will come about; a question that can hardly be answered. In 1996 Korea, Indonesia and Thailand had lower growth rates than before. The crucial question is whether or not this is the adjustment to a new long-run steady state value determined by total factor productivity growth or merely a transitory growth reduction due to the business cycle and an increasing dollar, which leads to an appreciation of those currencies which are tied to the dollar - baht ringgit, peso, won etc. In figure 1 the slopes of the bended curves are the growth rates if there is no impact of the dollar value but rather the views from growth theory apply. The straight lines indicate steady state growth paths. A transition form a lower growth path to a higher one initiated by the policies indicated in column 2 of scheme 1 would lead to such a transitional path with first increasing and later decreasing growth rates. A similar impression can be gained from the table 2 where the average growth rates for three periods are presented and from figure 2 where the actual growth of six countries is plotted.

FIGURES 1 AND 2 OVER HERE 
Table 2. GDP average annual growth rates in \%

$\begin{array}{lllll}\text { Country } & 1970-79 & 1980-89 & 1990-96 & \text { GDP per head } 1995 \text { \$ } \\ \text { Hong Kong } & 9.2 & 7.5 & 5.0 & 23,900 \\ \text { Singapore } & 9.4 & 7.2 & 8.3 & 22,600 \\ \text { Taiwan } & 10.2 & 8.1 & 6.3 & 13,200 \\ \text { Korea } & 9.3 & 8.0 & 7.7 & 11,900 \\ \text { Malaysia } & 8.0 & 5.7 & 8.8 & 10,400 \\ \text { Thailand } & 7.3 & 7.2 & 8.6 & 8,000 \\ \text { Indonesia } & 7.8 & 5.7 & 7.2 & 3,800 \\ \text { China } & 7.5 & 9.3 & 10.1 & 3,100 \\ \text { Philippines } & 6.1 & 1.8 & 2.8 & 2,800\end{array}$

Sources: IMF; ING Barings; national statistics; The Economist.

In terms of the upper more abstract graph derived from theory one could hypothesize that the four richer countries are in the more advanced phase of the transition with decreasing growth rates whereas the five poorer countries are in the less advanced phase of increasing growth rates. Countries from both groups are severely affected by the debt crisis. Thus being in one of these phases per se does not make a country more prone to being affected by the crisis.

However, it cannot be excluded from consideration that international investors may have recognized the phase of increasing and high growth rates of all these countries but have not recognized all to the same extent that some of these countries are already in the phase of decreasing growth rates. Such a lag in recognizing changes in growth rate developments may have contributed to too much optimism about the bubbles at the stock exchanges of all these countries which later led to some plunge (see table 3 below) in all of these countries.

The above reasoning being mainly based on closed economy growth considerations, one has to add the trade impact on growth: the slow down of growth in Japan will probably slow down the growth of the whole Asian bandwagon because Asian countries can export less to Japan.

The growth of the Asian economies has been based on industrial policy and not just the laissez faire captured by standard growth theory. It is well known that the 'tigers' have gained their world market shares at the cost of other developing countries, not the developed countries (see Todaro 1994). Moreover, they are taking over industries from each other. One often mentioned fact is that this may have led to overcapacity in Asia. What was coordinated at the national level in earlier years was not coordinated internationally in more recent years and also the national coordination did not work any more in some countries (see below). Again it is an interesting question whether or not international investors have been alert enough to see this type of a problem.

\section{The structure of the Asian debt crisis}

\subsection{Different views: where are the controversies?}

Sachs' view ${ }^{2}$ : sound fundamentals, almost pure panic. Unlike Krugman (see below) Sachs de-emphasises corruption and mismanagement. Economic reforms and financial liberalization in the Asian economies have attracted capital inflows. This induces an appreciation of the currencies. What investors rarely understand, he argues, is that during a later phase of debt 
services this appreciation has to be replaced by depreciation in order to generate the necessary export revenues. Banks being under-capitalized bear little risk themselves and expected bailouts secure them from risk. A combination of rising wage costs, competition from China and lower demand for Asian exports, all in connection with a revaluation of their currencies which were tied to the dollar which in turn appreciated, caused exports to stagnate. Foreign capital being invested in the non-traded sectors such as real estate banks and companies became unable to service debt. The result is a bank run although fundamentals are in order: government budgets are in balance or surplus, inflation is low, private savings are high, economies are poised for export growth. Although Sachs sees that there are current account deficits, overvalued exchange rates and a need for financial reform, he seemingly does not count these aspects as part of the fundamentals. It is here where Krugman differs in his view.

Krugman's view: moral hazard , national asset bubbles ${ }^{3}$. Krugman (1998a) has provided an interesting theory on the Asian debt crisis. In his view the essence of the crisis is a combination of moral hazard and asset bubbles. The argument in brief runs as follows. Suppose a government provides a guarantee for one bail out to financial intermediaries if they have bad luck and make losses. These intermediaries will ignore the possibility of bad outcomes of there projects because the government provides guarantees for these cases. Therefore they have higher expected returns than without government guarantees which encourages them to invest more than without the guarantees. Asset prices will therefore be artificially high. If bad luck occurs (a slump in the semi-conductor market and the rise of the dollar did trigger the crisis, but any little thing could have done so; see Krugman 1998c and below) or creditors don't believe in the future existence of the guarantees, the latter become due and investors have to take into account the possibility of future bad luck - now without guarantees - , therefore they calculate lower returns and invest less then before in these assets. Asset prices plunge. Foreign financial investors withdraw there money and, as an inessential by-product to the logic of the crisis the exchange rate collapses because of a reduction in the demand for the currency of the country in crisis. Moreover (see Krugman 1998b), as the guarantee, which was not given for foreign (direct) investors, vanishes, with less of a discrimination foreign direct investors now have a fair chance and buy Asian firms. This is an increase in efficiency to the extent that FDI sales are not merely due to the fact that the asset prices overshot into the downward direction.

Moral hazard and asset bubbles may indeed be an important aspect of the crisis.

Moreover, Krugman is aware of some limits of this view, some of which we will discuss in passing below. However, we have some more points of reservation. But before spelling them out we look at other views.

Stiglitz' view ${ }^{4}$ : between Sachs and Krugman. Stiglitz would agree with Sachs on the fact that there are many sound macroeconomic fundamentals. However, he differs from both Sachs and Krugman in pointing out misguided exchange rate and monetary policies, which are also part of the fundamentals. He would agree with Krugman that insufficient financial regulation and implicit or explicit government guarantees, poorly managed financial liberalization, misallocation of investment towards the real estate sector, unhedged short-term borrowing, high debt-equity ratios, are all weak microeconomic and institutional fundamentals.

What Stiglitz implicitly suggests is to broaden the set of fundamentals from a set of mere macro indicators to one of macro and micro indicators. This he has in common with Alan Greenspan's view. 
Greenspan's view: global stock market boom, overvaluation. Greenspan (1997) starts out from the observation of the World Bank that net inflows of long-term debt, foreign direct investment, and equity purchases to the Asia Pacific region were only about $\$ 25$ billion in 1990 , but exploded to more than $\$ 110$ billion in 1996. Greenspan's explanation is that in the global stock market boom - an aspect completely under emphasized by Krugman - of the 1990s, investors diversified their portfolios because they were heavily concentrated in the developed world where they had low rates of return. The money moved into the real estate sector of developing countries and these assets then served as collateral in a domestic financial system with lax lending standards, weak supervision and inadequate capital. The revaluation of the dollar to which these countries' currencies were tied made their exports less competitive. Current account deficits became unsustainable - an aspect completely deemphasised by Sachs. "The pressures on fixed exchange rate regimes mounted as foreign investors slowed the pace of new capital inflows, and domestic businesses sought increasingly to convert domestic currencies into foreign currencies, or, equivalently, slowed the conversion of export earnings into domestic currencies. The shifts in perceived future investment risks led to sharp declines in stock markets across Asia, often on top of earlier declines or lackluster performances."

Note that Greenspan does not say why there was a shift in perceived risk. However, he does seem to say that the speculative attack preceded the plunge of the stock market, whereas Krugman seems to say the opposite. For Thailand Greenspan (1998) is more explicit on this point: “..., it was apparently the lethal combination of pegged exchange rates, high leverage, weak banking and financial systems, and declining demand ... that transformed the correction into a collapse. ... The belief that local currencies could, virtually without risk of loss, be converted into dollars at any time was shattered. Investors, both domestic and foreign, endeavoured en masse to convert to dollars, as confidence in the ability of the local economy to earn dollars to meet their fixed obligations diminished. ... the weakening of growth also led to lowering profit expectations and contracting net capital inflows of dollars.... The combination of continued strong demand for dollars to meet debt service obligations and the slowed new supply, destabilized the previously fixed exchange rate regime. "Finally, we would like to state that Greenspan seems to have a clear view on the relation "...dangers of depositor run, following a fall in the domestic currency, escalate." This means that the speculative attacks precede the bank runs.

In Greenspan (1998) it is stated that moral hazard is a problem. However, it is also pointed out that some investors did suffer losses in the Asian crisis: Asian equity losses, excluding Japan, since 1997 worldwide are estimated to have exceeded $\$ 700$ billion of which more than $\$ 30$ billion has been lost by US investors. Substantial further losses have been recorded in bonds and real estate. This is confirmed by Fischer (1998).

Fischer's view: Pegged too long at high external deficits. Fischer (1998) emphasizes large external deficits and bubbles in property and stock markets. Pegged exchange rate systems have been maintained too long. That has encouraged external borrowing, with current account deficits strongly differing by country. Lax prudential rules and financial oversight led to a deterioration of the quality of loans. In the case of Thailand a confluence of domestic and external shocks revealed theses weaknesses. 18 months prior to the floating the government ignored IMF warnings and recommendations. However, Fischer does not discuss the moral hazard problem of governments bailing out domestic investors and attributes no role to international stock market developments. Speculative attacks are not mentioned but rather it is pointed to the hedging activities of domestic investors. 
As none of the authors refer to the others the controversies are very implicit. As a comparison of several positions is not a very easy task, we will summarize the various positions in scheme 3 below, making a distinction between the authors and whether or not they emphasize certain aspects in their explanation of the crisis. The emphasis on these aspects as explanatory factor are merely indicated by a crude distinction between 'high' and 'low', hopefully doing no injustice to any author. Below we will briefly interpret scheme 3 by way of just looking at the minority positions concerning each of the major explanatory factors.

\section{Scheme 3. The matrix of implicit controversies}

\begin{tabular}{|c|c|c|c|c|c|}
\hline $\begin{array}{l}\text { Author } \\
\text { Explanatory } \\
\text { factor }\end{array}$ & Sachs & Krugman & Stiglitz & Greenspan & Fische \\
\hline micro and institut & & & & & \\
\hline fundamentals ${ }^{c}$ & low & high & high & high & high \\
\hline $\begin{array}{l}\text { domestic macro } \\
\text { fundamentals }\end{array}$ & low & low & $\begin{array}{l}\text { Monetary } \\
\text { policy }\end{array}$ & low & low \\
\hline $\begin{array}{l}\text { international } \\
\text { fundamentals }\end{array}$ & low & low & low & $\begin{array}{l}\text { (un-)sustainable } \\
\text { current acc. }\end{array}$ & high \\
\hline moral hazard & low & high & high & high & low \\
\hline national bubbles & low & high & high & high & high \\
\hline $\begin{array}{l}\text { international } \\
\text { stock markets }\end{array}$ & low & low & low & $\begin{array}{l}\text { Diversification } \\
\text { withdrawal }\end{array}$ & low \\
\hline overvaluation & high & low & high & high & high \\
\hline $\begin{array}{l}\text { speculative } \\
\text { attacks }\end{array}$ & high & low & high & high & low \\
\hline
\end{tabular}

a national savings, government budget deficit, monetary policy and inflation, commitment to education, technologically advanced factories, egalitarian income distribution, aggressive pursuit of foreign exports (Stiglitz' definition).

b debt/GDP ratio, debt service/export ratio, current account, (foreign exchange reserves and adequate exchange rate treated separately)

c regulatory system, corporate governance, transparency (Stiglitz' definition)

We think it is obvious that the microeconomic fundamentals, moral hazard and national bubbles matter although Sachs and partly Fischer, both being advisors to governments, are de-emphasising them. We will discuss this item in section 2.2 under the header of financial excess. What we want to figure out there is i) that this aspect differs from country to country in an interesting way and ii) why bubbles burst: bad luck or overvaluations? 
Concerning domestic fundamentals all authors attribute a low importance to them with the exception of Stiglitz. All authors seem to agree that there is no problem with domestic fundamentals. Stiglitz' point concerning monetary policy is not explained explicitly but has to be understood in connection with his view that no inflation problem did exist. Supposedly he believes that monetary policy has been too strict. Is this reasonable under fixed exchange rates? Is there really no role for the fiscal deficits of these countries? Were inflation rates quite low so that the conventional currency crisis argument does not work? We discuss domestic fundamentals in section 2.3.

The only authors emphasizing the relevance of international fundamentals and stock markets are Fischer and Greenspan. Is the role of foreign debt and the current account really limited to capital flight and herding behaviour per se or do they play a role in the expectation formation of foreign investors? The question whether national bubbles (Krugman) or international stock markets are most important (Greenspan) is also worth some consideration. Krugman pretends that boom-bust cycles precede the speculative attack and the fall of the exchange rate whereas Greenspan seems to say the opposite. Have the boom-bust cycles prior to the currency crises themselves been preceded by the dollar revaluation? These issued are briefly discussed in section 2.4 .

The discussion in 2.4 will raise the question whether fixed exchange rates are viable when the dollar is rising for a long time but all other types of fundamentals are in order. We will argue in section 2.5 that this is not possible when the dollar rises far and long enough. And Stiglitz would probably add that flexible exchange rates give more room for less strict monetary policy.

All authors in some way agree that contagion or herding behaviour matter. Do we really have a case of herding behaviour explaining contagion under conditions of few economic links with the initial victims or are the links underestimated? This will be considered in section 2.6.

Finally, a point raised by Krugman himself is why the financial crisis produces such large slumps in growth in connection with real devaluation: is there a role for the size of debt in explaining the extent of the devaluation and a role for imported inputs in explaining the transmission to growth? And what about the credit crunch? We address this in section 2.7

\subsection{Forms of financial excess and the problem of forecasting}

\section{i) Financial excess I: moral hazard and asset bubbles: speculation on land, real estate and stocks in Japan and Thailand .}

The Japanese ${ }^{5}$ recession is lasting already seven years. The stock exchange and land prices fell already in the eighties. In the nineties real estate prices fell by $60 \%$ and the stock exchange by $50 \%$. Twelve banks have been closed. The growth rates of the GDP have gone down to between one and zero percent or even negative in 1997 from 3,5\% in 1996 to $-11,2 \%$ in the second quarter of 1997. Unemployment as measured by the OECD is 6,5\%. $40 \%$ of Japanese exports go to its Asian neighbours, which makes Japan rather sensitive against the Asian debt crisis. The 125 million inhabitants produce a GDP of $\$ 4200$ billion, which is ten times that of Thailand, Philippines, Indonesia and Malaysia together. The trade surplus was $\$ 132$ billion in 1995 . The value of foreign owned assets is $\$ 1000$ billion of which $\$ 300$ billion are owned by American citizens. The major debtor in the crisis region is Hongkong, a fact which gives some safety to the Japanese and the world system as long as Hongkong is not a 
major problem in the crisis. Central bank reserves are the highest in the world: $\$ 230-330$ billion depending on the source

\section{Table 3. Financial aspects of the crisis}

\begin{tabular}{|c|c|c|c|c|c|}
\hline $\begin{array}{l}\text { Country } \\
\text { Crisis features }\end{array}$ & Korea & Indon. & Thailand & Malay. & Jap. Philip. \\
\hline debt/head ${ }^{\mathrm{a}}$ & $156 / 45$ & $144 / 200$ & $90 / 60$ & $<45 /$ & \\
\hline debt/GDP & $156 / 435$ & $144 / 190$ & $90 / 130$ & & $10 / 42$ \\
\hline $\begin{array}{l}\text { devaluation } \\
x \% / \$^{b}\end{array}$ & $>69$ & $>142$ & $<84$ & $>54$ & $<13^{c}$ \\
\hline $\begin{array}{l}\text { financial } \\
\text { excess }\end{array}$ & Chaebol; & family & & & Bureaucrac. \\
\hline bubbles & $\mathrm{SE}^{\mathrm{d}}$ & SE & SE, land & SE & land, real estate,SE \\
\hline major credit. & $\begin{array}{l}\text { Japan. } \\
\text { and US } \\
\text { banks } \\
\text { Chaebols! }^{\mathrm{e}}\end{array}$ & $\begin{array}{l}\text { Japan }(>22 \mathrm{bn}) \text {, } \\
\text { NL 5\%of } 144 \\
\text { Deut.Bank\$10k }\end{array}$ & $\begin{array}{l}37,5 \text { bnJap. } \\
\text { banks } \\
\text { b. }\end{array}$ & & USA \\
\hline IMF prog. bil. & $\$$ s $\quad 57$ & 43 & 17 & none & Cont. \\
\hline
\end{tabular}

\begin{tabular}{|c|c|c|c|c|c|c|}
\hline & Hongk. & Taiw. & China & India & Singap. & Vietnam \\
\hline \multicolumn{2}{|c|}{ devaluation } & \multicolumn{4}{|c|}{$x \% / \$(\max )}$. & $>5$ \\
\hline \multicolumn{5}{|c|}{ Financial excess } & & $\begin{array}{l}\text { SOEs } \\
\text { Corruption }\end{array}$ \\
\hline Bubbles & SE & & & & $\begin{array}{l}15 \% \text { real } \\
\text { SE? }\end{array}$ & \\
\hline
\end{tabular}

major creditor Japan

S-Korea

a values are those revealed afer the debt crisis after it had turned out that official data of the IMF and BIS suffered from underreporting; GDP and debt are measured in billion dollars and population in millions.

b With the exception of the values for China, India and Vietnam which are collected from the daily press these values are taken from "A Chart of the Collapsing Currencies" from “ http://www.stern.nyu.edu/ nroubini/asia/chart.html” . Exchange rates on Dec 161997 are compared to those of Jan 21997.

c Since April 1995 the yen has lost 30\% against the dollar.

d Stock exchange

e $\quad$ Chaebols are owners of Korean banks (Time Magazine Jan 12 1998)

f This was at least partly due to the introduction of a $100 \%$ tax on profits from selling buildings within one year.

Other sources: Economisch Statistische Berichten, Financial Times, J.P. Morgan (Robert E. Litan 1998), de Volkskrant; Die Zeit;

and the valuation. Households have cumulated savings of $\$ 10.000$ billion, twice the GDP value although there is strong financial repression limiting interest rates received by households to $0.5 \%$. Reforms in all areas of society are overdue (in particular in regard to the 
sokaiya phenomenon) because the planning of the social system had been based on a growth expectation of $6 \%$. Here the long-run trend of slowing down growth rates as motivated by figure 1, which has reduced export growth in Thailand, South Korea and the Philippines, has still to be taken into account. The Japanese crisis is mainly one of the banking sector - to which the combination of moral hazard and asset bubbles applies - and will remain being so unless Hongkong is becoming part of the debt crisis or many countries' reduction of growth really harms Japanese exports. So far Japan has been important for the onset of the crisis because of its slow down of growth and the devaluation of the yen which contributed to starting up the crisis and the above mentioned reduction in export growth of other countries. In table 3 the devaluation is only 13\% for the 1997 but compared with April 1995 the devaluation against the US dollar is $30 \%$.

In Thailand ${ }^{6}$ the crisis broke out on July 2 1997. The stock market index had gone from 1400 in 1995/6 down to 700 in beginning of 1997. Until the end of $199620 \%$ of the loans lent to property investors had gone bad. Its exchange rate was tied to a basket of currencies dominated by the dollar but not in line with their trading pattern and as the dollar had strengthened against the yen so had the baht for more than two years and therefore, in connection with the weak growth in Japan, exports fell in 1996. Thai banks had borrowed in dollars and lent in baht where the interest rate was much higher, indicating an expected devaluation. This means that they gambled on stability and lost later in July. Somprasong missed payments on foreign debt in February 1997. The Bank of Thailand defended the baht on Feb 14 spending \$500m after Moody's had announced a downgrading of Thai debt. On march 3rd trading in bank and finance-company shares had been suspended. 400 billion baht ( $\$ 15 \mathrm{bn}$ ) of property loans have gone bad before may 17. By may 15 the baht was hit by an unsuccessful, massive speculative attack. The central banks of Thailand and Singapore intervened and drove the interest rate to $1300 \%$; the stock market did go to an eight year-low falling by $65 \%$ since the start of 1994. On May 23 Finance One, Thailand's largest finance company, could not be saved. On June 19 the minister of finance resigns because his resistance against devaluation is no longer accepted and the Thai baht plunges for the first time at a large amount. On June 27 the Thai cental bank suspends operations of 16 cashstrapped finance companies and announces the managed float on July 2 after assuring that there will be no float on June 27 - domestic credit had reached a level of 160\% of GDP. Unhedged borrowers of dollars go bankrupt because of increased costs of servicing debt. On July 28 Thailand calls the IMF (and the Reserve Bank of Australia after having been denied help from Japan (the largest creditor country), Singapore and China) which announces a package of $\$ 17$ bn on August 11. The ensuing credit crunch together with the devaluation will hamper imports of capital goods and slow down the transition to more capital-intensive production which needs more imported capital goods. Moreover, from October 1997 till October 1998 another $\$ 40 \mathrm{bn}$ fall due. More detailed information can be taken from table 3. To sum up, the revaluation of the dollar preceded non-successful attacks, leading to the fall of the stock market index, and finally successful speculative attacks. For Thailand we can safely say that the dollar revaluation and the property price bubble preceded non-successful speculative attacks and the stock market decline preceded a successful speculative attack. The crisis did also spill to other financial markets.

Malaysia had provided incentives to merge banks before July and to open for foreign banks, but this had almost no effect. The antiquated financial system has suffered from property lending as in Thailand. Current account deficits were large (see table 4 below) and politicians seem to have an inclination towards prestige projects, however, without generating 
a large government deficit (see table 4 below). Overbuilding in the property sector is much less than in Thailand. After the devaluation of the baht on July 2nd, a speculative attack has been fought successfully raising overnight interest rates to over $50 \%$. More flexibility of the ringgit is allowed for on July 11th. President Mahatir's attacks against Mr. Soros began end of July when the devaluation of the ringgit had been no more than 10\% (not more than European currencies had lost against the dollar) - the larger part of the 54\% denoted in the table 3 was still to come. Mahatir's attacks against speculators provoked fears of capital control leading to another fall of the ringgit by $4 \%$ on October 1st, reducing its value to $25 \%$ below that of July. As a result the until September the stock market had lost 40\% during 1997. For Malaysia we can safely say that the causation goes from speculative attacks to the stock market. The crisis is a consequence of that in Thailand which in turn was caused by property bubbles and a fall in the stock market both after devaluation of the yuan and the yen and the revaluation of the dollar.

The Philippines are the poorest of the countries in Table 2. In $198582 \%$ of the children were malnourished according to UNICEF. In $199147 \%$ of the islands population were living in poverty. Recently they had high growth rates (export growth for 1997 was expected to be more than $20 \%$ or even $30 \%$ before the crisis), a central bank with a reputation for independence and tough supervision and foreign banks which had raised the standards of banking. The government did raise capital requirements in December 1996. However, the banks had nevertheless been involved with property woes. Middle of May the country is affected by the speculative attack, right after that on Thailand; on June 19th the interest rate is raised to $15 \%$, and to $24 \%$ on July 3 rd and to $30 \%$ after an attack on July 7 th. On July 11 th the peso floats freely and falls by $10,5 \%$, which became $56 \%$ over all 1997 . The stock markets did plunge as well. Property woes had made the country sensitive for a speculative attack although fiscal deficits and the current account are rather small (see table 4 below).

\section{ii) Financial excess II: moral hazard with and without asset bubbles: From Petrobras to the Chaebols in Korea.}

In Korea the moral hazard phenomenon is best known ${ }^{7}$ in regard to the Chaebols, large conglomerates which had access to much credit because of its good relations to the government. This exaggerated excess to credit was one of the reasons why it was possible for Korea to leave the strategy of increasing returns by picking the winners. Large firms using credit money to produce the same goods as their domestic competitors are a drastic change in strategy. However, this all was known long before and it is structurally similar to the role of Petrobras in Brazil and the SOEs in other countries in the 1982 crisis (although the connection with the stock exchange may be stronger in the Asian debt crisis). The only question was when the trouble would come to burst out. Although $\mathrm{Korea}^{8}$ was told to have its capital markets much less liberalized then other countries it turned out after the outbreak of the crisis that they had received too large a volume of loans (see table 3) - with no obligation to disclose information, let alone make provisions against, all of their suspect loans. Growth rates had become slightly smaller since the beginning of the 1990s and some Koreans had already understood that there long-run growth would be that of the increase in productivity and that the transition indicated in figure 1 may be more or less over. It was also known that many firms owing credit were virtually bankcrupt, and loans had to be paid back within one year and even earlier the practices of inefficient use of capital and labour due to corruption etc. were warned against. After the downturns in the semiconductor, metals and petrochemicals businesses in 1995 and 1996, firm bankruptcies were more or less a continuous event in 
Korea: Hanbo collapsed in January 1997, Sammi in March, Jinro (rescued) end of April, Kia was close to collapsing in July, Korea First Bank was rescued in August, and in October Sangbangwool came into trouble. The debt-equity ratios of more than 170 large companies are larger than $500 \%$, the largest 300 having ratios three times as high as large American firms. Moreover, the stock exchanges of Thailand and Korea had been developing much worse in 1996 than those of other emerging markets, a clear sign of caution from investors (ECN 97 Feb 22). By March 31st 38 firms of the Korean Stock Exchange had recorded a combined loss of $\$ 700 \mathrm{~m}$ on proprietary trading. In April 1997 the president of Korea had come up with a financial reform package trying to rescue banks by involving the chaebols, who partly own them, obliging banks to extend credit even to firms that have defaulted before and setting up a Korea Asset Management Corp to buy loans at a discount from banks and then try to recover the lost funds, thus financing the bail-outs. Nevertheless a credit squeeze is beginning to hamper the industrial sector in June. Obviously the outbursting of the crisis could have been prevented if earlier measures had been taken and the problems had not been hidden by falsifying statistics: In the official statistics total debt as a share of GDP was no higher than $15 \%$; however, table 3 indicates that it turned out to be $\$ 156 \mathrm{bn}$ which is more than $40 \%$ of the GDP of $\$ 366$ bn (or only $\$ 238$ bn according to table 2; value depend on the exchange rate used in the computation) and even higher if the devaluation is taken into account when computing the GDP in dollars. The logic here clearly goes from sectoral problems and moral hazard on the side of the chaebols to the stockmarket and from there to a devaluation.

iii) Financial excess III: more than just moral hazard: families, corruption and all that in Indonesia.

The political situation in Indonesia is what Krugman has in mind. Corruption, a shaky banking system, the slow pace of deregulation and dismantling of monopolies, and a lack of legitimacy forcefully expressed by the omnipresence of soldiers and the screening of campaign speeches in Indonesia are well known. Moreover, due to deregulation since 1983, the number of commercial banks exploded in Indonesia. But the country's central bank failed to step up its monitoring of the risks involved. Banking scandals and collapses became commonplace because of dodgy loans to families and conglomerates. As the Philippines and Malaysia, the country has large foreign debt (see table 3), but lower current account deficits than the Philippines (see table 5) but higher inflation of $10 \%$ before and $60 \%$ after the crisis (see table 4). Much bank lending going to property investment (three quarters of the land are owned by the government), a fixed exchange rate with the dollar and slowing of exports. It dropped the band and allowed the rupiah to float on August 14. However, the trouble did go as far as (see table 3) a devaluation of $142 \%$ and a debt of \$144bn (after official data told it was $\$ 55 \mathrm{bn}$ before the crisis) that is larger than that of Brazil and Mexico was in 1982 (each about $\$ 100 \mathrm{bn}$ ), although Indonesia is much poorer. The IMF program of about $\$ 43 \mathrm{bn}$ is correspondingly large. Non-solid policies on all relevant aspects except for fiscal and current account deficits, the IMFs most beloved criteria, have made the country sensitive for competitive devaluations and speculative attacks.

iv) Financial excess IV: The situation in China can be summarized as fragile banking with little foreign capital and real effects. The Chinese banking system (see ECN 97 Apr12) is characterized as 'primitive, state-dominated, unstable and mired in debt'. One fifth of all loans have turned sour. Transparency is characterized as 'very poor' by Moody's. Why then has China not been part of the crisis? The yuan has been undervalued in January 1997. The central bank of China has accumulated large reserves by buying dollars, thus exerting upward pressure on the yuan. Its current account is in surplus and capital inflows are of long term 
loans, not short-term. Therefore may be the yuan is unchanged until April 1998 since its devaluation in 1994 ?

A similar case is Vietnam. Growing at 9\%, foreign aid and investment are coming in and inflation is under control. However, state banks lending to state owned enterprises as well as corruption pose some problems. The current account deficit is $15 \%$ and reserves are low, at $\$ 1.6 b n$. The debt is owed to Korean companies. Viet Hoa Bank has refused to repay some deposits in May 1997. Information is the worst of all countries here. After the crisis there has been a devaluation of $5 \%$.

v) No financial excess: no real crisis occurred after the crash of the stock exchange in Hongkong and Taiwan.

The Hongkong-dollar is unchanged until April 1998. Property prices were rising through May 1997. The Hang Seng Index drove to records until July 3rd, the day after the baht devaluation. Expectations of bursting bubbles were first formulated in ECN 97 Jul 12. Interest increases on August 15th to defend the Hongkong dollar let the stockmarket plunge by $2.4 \%$ and $4 \%$ on the next trading day. Reserves were high enough to fight the attack. However, when Mahatir attacked Soros even the Hongkong stockexchange did fall $15 \%$ and again in October speculators did try to find out whether the authorities are willing to defend the overvalued HK dollar inspite of increasing interest rates. Asset bubbles without moral hazard need not be harmful. The question, however, is whether or not the Hongkong currency board could have survived if the increase of the US dollar to which it is tied had been going on longer. For Hongkong it is clear that the causality goes from speculative attacks to the stockmarket.

No high debt, large reserves, no financial excess could be seen in Taiwan. Property markets had been down since medio 1994. Concerning shares the Taiwan Weighted Index rose by 34\% in 1996 and the Over-the-counter securities market (OTC) by 136\%; growth in issuance outstripped growth in money supply in July 1997, indicating a coming slow down. The defence of the NT dollar in October did increase interest rates, driving the stock exchange index down by $20 \%$ since August. Taiwan has the world's third largest reserves. Taiwanese firms started buying firms in Thailand, Philippines, Malaysia and Indonesia in 1998.

Devaluations had been modest in comparison to the crisis countries and the current account is in surplus as in Singapore (see table 3). For Taiwan it is clear that the causality goes from speculative attacks to the fall in the stockmarket.

Who speculates and who gains? As in earlier Mexican crises, in East Asia biggest sellers of local currencies have been not speculators but local firms trying to hedge or repay debts denominated in dollars. It is remarcable that in Thailand the banks report losses from the stock divisions but gains from the foreign exchange divisions for 1997. Maybe President Mahathir can gains some information from investigating Malaysian banks. From this point of view a profit tax on foreign exchange gains may be an alternative for the Tobin tax worth a discussion. The question is whether or not it could be as successful as the tax on profits from land and real estate speculation imposed by Singapore.

But we also want to question the view that moral hazard can generate an asset bubble in stock markets of an open economy with capital flows. The point is that foreigners and domestic people seeing that governments induce inefficient measures which have an effect towards generating bubbles will know these inefficicies and the high probability that these bubbles burst. If they therefore do not put their money into these stockmarkets but rather keep out the net effect may be having no bubble at all. The question is how many actors are that rational and well informed. 


\subsection{The role of domestic fundamentals: Were fiscal deficits and inflation irrelevant?}

Boonstra and Möller (1998) argue that inflation was a bit higher in these countries than in the US although deficits were moderate or even absent (see table 4 below). Currencies being tied to the dollar become overvalued. Current accounts did get negative and money inflow did finance this. Short term lending did prevail. This is the classical situation of currency crises although it does not need high deficits (the major example of the early literature on currency crises; see Krugman 1997b) to have inflation. However, it is important for such a claim to have also decreasing reserves. Moreover, in Korea and Malaysia the inflation rate was only marginally larger than that of the US. Here it is more promissing to search for a role of the revaluation of the dollar (to which these currencies were tied) and the devaluation of the yen (which increased Japan's export prospects) if there is anything at all that can undermines Krugman's position. Given this macroeconomic information one could also argue that the speculative attack would have come anyway; property woes and weak chaebols made them merely successful at a somewhat earlier date.

Stiglitz believes that monetary policy is inadequate. This is hard to judge about because a less anti-inflation oriented policy is possible only under flexible exchange rates. An option that has not been chosen by the countries in question and not even by the developing countries that had been hit hardest in the 1982 crisis. They have merely broadened the bands of more or less fixed exchange rates (see Calvo et al. 1994).

Table 4

$\begin{array}{llll}\text { Country } & \text { Korea } & \text { Indon. Tha } \\ \text { Fiscal deficit } & -0.2 & 0.7 & -0.8 \\ \begin{array}{l}\text { Inflation \%e.a. }{ }^{\text {a }} \\ \text { Inflation \%e.p. }\end{array} & 4,3 & 10 & 7 \\ \begin{array}{l}\text { Reserves, } \$ \text { bn } \\ \text { debt due next }\end{array} & & 60 & \\ \begin{array}{l}2 \text { years } \$ \text { bn }^{\mathrm{c}} \\ \ldots \text { and divided }\end{array} & 74 & 38 & 50 \\ \text { by reserves in\% } & 200 & 200 & 120\end{array}$

a 1997 before the crisis; Source: Boonstra and Möller (1998)

b After the crisis

c According to Peter Mortagnon, The bamboo curtain rises, Financial Times, 1/30/98.

Table 5

Country Korea Indon. Thailand Malay Singa. Taiw. Philip. Jap. Vietnam

current acc.

Surplus \%GDP ${ }^{\text {a }}$

$\begin{array}{lllllllll}1996 & -4.9 & -3.4 & -7.9 & -6.3 & 15.2 & 4.0 & -4.5 & -15 \\ 1997 & -2.7 & -4.5 & -4.2 & -9.9 & 16.2 & 1.8 & -2.9 & \end{array}$

a Sources: J.P. Morgan, Financial Times, Robert E. Litan 


\subsection{The role of international fundamentals and the US dollar revaluation}

Concerning international fundamentals we see from scheme 3 that Greenspan and Fischer emphasize them more than the other authors. De Ruyter van Steveninck (1998) and Boonstra and Möller (1998), both bank employees, argue that the revaluation of the dollar made the currencies of the crisis countries overvalued. In connection with a devaluation of the Chinese yuan in 1994 and the Japanese yen, they argue that the current accounts became negative. This made the stock exchange plunge. In connection with the difference in inflation discussed above this may have led to the pessimistic expectation which are so crucial in Krugman's theory. From reading Krugman (1998a) and the view of Boonstra and Möller (1998) one might get the impression that unlike Krugman these authors put financial excess into the second most prominent place and the traditional arguments into the first place. However, Krugman is more clear on this point in his 1997b paper (page 11): the argument is that the dollar revaluation undoubtedly came first but it was not directly followed by speculative attacks but (before that) by the collapsing of the stock exchanges - at least in the case of Thailand. What should be verified therefore is that the order of happenings is 1. Dollar revaluation, 2. Collapse of stock exchange, 3. Speculative attacks and reductions of reserves.

For Thailand we can say that indeed stockmarket went down in the beginning of 1997, non-successful speculative attacks occurred in February and May, leading to another fall of the stockexchange and finally the baht went down and floated in june and july respectively. This is exactly the pattern krugman has in mind. For Korea the stockexchange went down in 1996 and attacks and evaluations came later; again krugman has it right. For all the other countries, however, speculative attacks lead to high interest rates, a fall in the stockexchange and finally to devaluations. Here the causality goes the other way around.

Krugman's point then is that speculative attacks are a consequence of the collapse of the stock exchange and would not have happened without it from the dollar revaluation alone. Moreover, Krugman (1998c) argues that inspite of the actual role of the dollar revaluation any little thing could have triggered the crisis because a bubble was underway that will burst anyway. However, we would like to argue, the revaluation of the dollar has led to more than two years of increasing deficit accumulation on the current account, growing short term debt and decreasing reserves in defence of the fixed exchange rate. The reversion of all these developments may be rather costly and could have been prevented at least partly under flexible exchange rates as in the 1982 crisis. Finally, after the baht floating there have been many countries whose currencies came under speculative attack; these were exactly those countries which had banking problems and too tightly fixed exchange rates - obviously exchange rates matter here.

The crucial point might be that it is not just bad luck that has stopped the bubbles but rather slow growth from Japan, the devaluations of the yuan, the yen and the revaluations of the dollar. In brief, how obscure a bubble one can have depends on how large growth rates are. If they fall bubbles burst (see Noland 1998 on this point).

\subsection{The non-sustainability of fixed exchange rates when the dollar is rising}

Stiglitz has recently gained some reputation as a protagonist of lax monetary policy. Of course, he will know that this is out of reach with fixed exchange rate policy. The reason is that it is standard knowledge now that fixed exchange rates can only be sustained if all other policies are compatible with the target exchange rate (see Krugman 1997c). Otherwise a country will induce speculation against its currency. Another standard lesson is that there are 
only two systems that can avoid speculation with certainty: monetary union and flexible exchange rates.

These two standard lessons, however, induce a question which seemingly has not been explicitly treated anywhere: does there always exist a policy combination that can ensure a fixed exchange rate or are there situations where a fixed exchange rate is not sustainable even if all fundamentals are sound? This seem to be important questions because it is always the debtor countries with fixed exchange rates which are hit most severely by the debt crises when the dollar is rising. In 1982 these were the Latin American countries who did stick to fixed exchange rates too long after Volckers anti-inflation policy raised interest rates and the value of the dollar. In that crisis the Asian countries were praised for the exchange rate flexibility. Now, in the Asian crisis, they themselves did stick to fixed exchange rates, a situation which looks unsustainable. Why? The answer runs as follows.

Divide the world into three parts: the country in question, say Korea, the country to which it ties the won, say the USA, and the rest of the world (ROW). As the won is tied to the dollar we assume that the trade balance with the US will not change. Furthermore we assume that it is balanced and by implication we can ignore the US part of the Korean trade balance but not the trade balance with the rest of the world. Now suppose that the dollar is permanently and continuously revalued and therefore the won is revalued vis a vis the currencies of the ROW. Of course, deficits arise with ROW and overvaluation will attract speculative atacks, unless monetary supply is permanently reduced and the country converges to a monetary union with the US. The IMF did know this, but the Thais did not believe it.

2.6 The Pro's and con's of contagion views. 'Contagion' is defined in various ways. Fischer (1998) says that 'some contagion reflected rational market behaviour'. Defined that broadly it does not mean more then the spreading of a phenomenon, here the crisis. If this spreading is based on the observation of large current-account deficits, property gluts and sizable unhedged foreign debt, there is no doubt that contagion exists. Things become more controversial, however, when it is claimed that contagion occurs, defined as the spreading of a crisis inspite of no rational reasons but just sunspots.

Typically, this argument then says that neither trade relations between two countries nor portefolio interactions or any other rational arguments justify that the crisis spills over from one country to the other.

Rational contagion occurs when the crisis jumps from Thailand to its closest competitors in exports. These competitors then also will have to devalue there currencies. This in turn effects the currencies of again other competing countries which may be closer competitors to the infected country than to Thailand. In Krugman's view these relations do not exist between Mexico and Argentina. However, the crisis of 1994/5 did spillover from Mexico to Argentina; this could be called irrational contagion if no other rational explanation is found.

Another variant of rational contagion would be a spillover to countries from which Thailand or Korea buy their imports: they have worse prospects for their exports.

A third link, however, has not been debated. Some East Asian central banks have an agreement to help each other in defending their exchange rates. If they really do so, and they did, then they run down their reserves simultaneously. A change in the equilibrium exchange rate with the yen, brought about by pegging to the dollar which was going up, and therefore bringing pressure on the dollar exchange rate, will increase the probability of devaluation of all these currencies if they have less reserves to defend them. Then, a common devaluation 
again does not reflect contagion but just a co-movement of reserves and the non-crediblity of a successful defence.

A fourth link is the common weakness of the banking system. Any speculator could read in The Economist from April 12, 1997 that dollars 250billion had been spent on cleaning up banking crises in the past and that banks from Thailand, South Korea, China, Indonesia, Vietnam, Malaysia and the Philippines have or might shortly have banking problems if property woes worsen. This seems to be rational reason enough to try a speculative attack one month later after the baht had been floated, certainly in connection with the previous argument of a common defence obligation - of course not for countries that have little short-term bank loans like China and Vietnam.

When the Hongkong stock exchange fell end of October 1997 Latin American stock exchanges lost about $15 \%$. The Bombay stock exchange fell by $23 \%$. Are the links underestimated? Greenspan (1997) states that "One can debate whether the turbulence in Latin American asset values reflects contagion effects from Asia, the influence of developments in U.S financial markets, or home-grown causes." So far contagion remains an open issue (see also Doukas (1989), Eichengreen, Rose and Wyplosz (1996) and Ziesemer (1997a, chap. 7.6) on this point.

2.7 Causes and consequences of real devaluations. Consequences are more easy to analyse. Krugman (1998a,c) frankly admits to be surprised how large the real effects of the crisis are. He explains the real effects as follows. Partly, people feel poorer, depressing consumer demand. Partly, low stock prices and high interest rates are depressing investment demand. But also profitable companies are hamstrung by lack of credit. This sounds very much like a non-international economists answer from one of the leading international economists. So may be we should add that in all of these countries food is imported and capital goods are imported and both become much more expensive after the devaluations. With more expensive imported inputs investment may be less profitable. Even larger exports will hardly be able to compensate this. Moreover, international trade credit seems to be a problem for some time because as long as there is uncertainty about the value of the currencies and too much money has been lent banks don't borrow more money. This credit crunch inhibits growth in all debt crises (for two possible formalizations see Ziesemer 1997a, 1997b, 1998). All these effects will slow down growth as they did in the Latin American Debt Crisis, where trade balances became positive mainly by reducing imports.

\section{Various aspects}

\subsection{Why didn't anyone see the Asian Crisis coming?}

This is an offen heard question not only after the Asian crisis had broken out, but also in the 1982 crisis. It should be clear that in both crises many had actually predicted the crisis. On the 1982 crisis the reader will find an interesting piece of literature in the comments on Solomon (1977) and in a footnote in Sachs (1981).

Here is Paul Krugman's view on the Asian crisis. . " ... Asians did invent a new kind of crisis, ... An off-the-books crisis. ... hidden liabilities .... that weren't exactly publicly guranteed, that weren't exactly not publicly guaranteed. ... a culture in which the line between what is private and what is public was not well drawn, and we're not used to that. We weren't used to it. We didn't know how to read the statistics. We didn't have statistics. The other 
thing is ... somone who said I see some risk out there tended to be argued down .... And so people were lulled into a false sense of security. "The first part of all these sentences sounds familiar from what has been said after the 1982 crisis. That part of Krugman's statement is correct but not new. IMF, IIF and the BIS simply have not solved the observation problems, although part of the information necessary has been available but not used (see endnote 7 again). The latter part is more convincing. Why? I would have put the answer to the question of this section differently.

First, most people are not busy with making predictions.

Second, those who are making predictions do so because they have the incentive of having put their money somewhere where risks may exist. If they have produced information telling that risks are 'out there', the most stupid thing to do is to publish this information because doing so makes others withdrawing there money which would devalue the publishers own investment. Therefore they will be silent and try to withdraw their money without losses before others have the information.

Third, the supervisors of the investors and intermediaries like the IMF are afraid to trigger panics and runs by publishing their information. However, the IMF has been in dialogue with Thailand 18 months before the crisis. May be they predicted the crisis but did not publish the prediction.

It seems to me that it is the latter point which needs some more sophistication. Of course, the IMF should not publish news for the first time when they have bad news because this could trigger a panic. What the IMF however, may be could do is to announce that it will publish a system of debt indicators (see Ziesemer 1997a, chap. 9.1 for such a system) after a year or two after the announcement. This gives time enough for badly performing economies to bring their policies in order. The publications then would make sure that there is no investment in badly governed economies and governments having to anticipate that would keep their economy in order. Employment in the IMF would probably be restructured towards cooperation with the BIS and IIF and the making of this information. However, the question is whether or not the quality of the information which the IMF receives from the countries will deteriorate. Countries now could improve there attractiveness to investors by presenting themselves better with biased information, a problem well known from firm's accounting practices. If this problem cannot be overcome by supervision and control we may have to choose between, on the one hand, the current situation of good IMF information which is not available publicly but useful to the IMF job, and on the other hand between public but worse information. The problem is whether or not national accounts etc. can be controled as good as balance sheets of firms.

\subsection{Transmission to Europe and the USA}

$30 \%$ of US exports go to Asia (including non-crisis countries). These exports may decrease. However, only $4 \%$ go to the MIT countries and the Philippines, and $12 \%$ to Hongkong, Singapore, Korea and Taiwan, which are only slightly effected with the exception of Korea. Japan sells $40 \%$ of its exports to developing Asian countries and Europe only $7 \%$. As a share of GDP it is only $2 \%$ for the USA and Europe and $4.4 \%$ for Japan. The direct effects will be small for Europe and the USA. For Japan they will be less than a half percent which is a lot in times of negative growth rates.

However, the indirect effects are normally underestimated. 
The role of devaluations and overcapacity will probably be more important. After the devaluations they may bring their foreign direct investment (fdi) home because exports become more profitable relative to FDI. That could cost some jobs in the US and Europe.

Finally, welath effects may come from ownership of Asian firms, which generate capital losses for European and American firms who partly own Asian firms which are in trouble.

5\% of dutch exports goes into the Asian region. In October 1997 there is no impact of the crisis on dutch exports.

As the GDP of Japan is ten times that of Korea and ten times that of Thailand, Philippines, Malaysia and Indonesia, a one percent decrease of its growth rate does about as large as a ten percent decrease in growth of either Korea or the other four countries. My overall estimate is that neither of these events will do much harm in itself but together they may.

\subsection{Remarks on IMF policies}

Fischer (1998) defends the IMF policy of raising interest rates after the crisis pretending to know the high interest rates are less damaging than large devaluation. It is hard to see on which quantitative assessment this can be based. We are not claiming the opposite but we want to point out that there seem to be some unclarified points about this.

The problem is as follows. Suppose that without IMF interference there would be a devaluation of $100 \%$. What are the consequences for investors and consumers/workers?

For an investor this would double the price of an imported machine. Now suppose alternatively that IMF interference would increase interest costs by more than $100 \%$ but would avoid some percentage points of the devaluation. The question then obviously is, is the reduction in devaluation large enough to outweigh the costs of an increase in interest rates. Do we have any quantitative assessment of this type of a problem or does Fischer just present an informed guess?

For consumer/workers the problem is even more involved. If food is imported its prices would also double. An increase in interest rates may, for example, increase the unemployment rate from $5 \%$ to $12 \%$ and for the employed it may decrease the nominal wage. The induced avoidance of devaluation would have an immediate benefit on consumer prices, but employment and wages prospects would decrease. Can we say what is better?

\subsection{Is the Asian Miracle over?}

On the one hand it seems premature, however, to conclude that the times of high growth rates are over. If the 'tigers' will in the long run have the same TFP growth as the old OECD countries, they may approach the same path as the latter. Hongkong and Singapore, having still much lower incomes than other cities in the world, have of course some further potential for catching up. The same is true for Korea and Taiwan which have reached income levels comparable to the poorer old OECD countries but have quite a way to go to reach the levels of the richer OECD countries. Moreover, Singapore, Hongkong and Taiwan are not strongly affected by the crisis.

However, if one does not believe in the TFP growth rate results used above (see Krugman (1997a, last paragraph) the prospects of course may be more pessimistic. Moreover, countries like Thailand and Indonesia have invested much less in human capital than the others and may therefore expect an earlier slow down running into decreasing returns to 
capital and labour. Korea seems to have a serious conflict about the power of the chaebols which the new president wants to split up and Indonesia has social unrest and is getting back its migrants from Malaysia. Therefore for Korea, Thailand and Indonesia, the seriously affected countries, the prospects are not too gloomy.

The big questions, however, for all of these countries, will be whether or not the slow down of Japanese growth will be replaced by growth of China and India and how long the credit crunch keeps them from recovering. Latin America and Africa had a lost decade. World economic growth is more favourable for the Asians than it was for them.

\subsection{Non-informative statements}

Given all that has been said in this atricle the reader is warned of some undifferentiated statements about the crisis that could be found in the business press. Here are two of them.

"SMH has 33 billion DM - 7\% of its credit volume - invested in Sout-east Asia". This suggests that the bank is highly endangerd. However, if they have most of their money in Singapore and Hongkong as the Deutsche Bank has, this danger is much less because these countries are hardly effected by the crisis.

"European banks have DM 650 billion loans outstanding in the Asian region, German banks more than DM 100 billion." The same comment as before applies. For comparison, Standard and Poor's estimates that European banks have DM 260 billion in the four crisis countries Korea, Thailand, Indonesia and Malaysia. That means that only $40 \%$ of these loans are in the crisis countries.

\section{Summary and conclusion}

The major arguments of this paper can be summarized as follows.

1. Although this is an ongoing debate, growth of the Asian economies seemingly came predominantly from factor accumulation, not from total factor productivity growth and therefore could be expected to slow down at some point in time.

2. All types of fundamentals - macroeconomic, institutional and other microeconomic, domestic and international - should be taken into account when judging about risks.

3. Devaluation of the yuan, the yen, revaluation of the dollar and the growth slow down in Japan all have induced a reduction of growth of exports of the Asian NICs.

4. In Thailand and Korea property and Chaebol woes preceded speculative attacks and devaluations; in other countries speculative attacks came first.

5. As in Mexico 1994/95, in Thailand (at least), some domestic sellers of domestic currency did gain. Those who did loose could have known about the woes earlier.

6. In the problem countries inflation was higher than in the USA. Developing country standards for inflation are irrelevant when the currencies are tied to the dollar.

7. Problems did arise in countries which had both, a weak banking sysytem and fixed exchange rates. Deemphasizing any of these two aspects is somewhat arbitrary.

8. Only monetary union or flexible exchange rates can avoid speculation with certainty.

9. Fixed exchange rates with the dollar are not sustainable if the rise of the dollar lasts long enough.

10. Contagion, in the sense of irrational spillover of the crisis, remains a controversial issue. Empirical research so far has not taken all relevant arguments into account. 
11. There exists a trade of between the secrecy and the publicness of crisis indicators: either the information is secret and of good quality or the information is public but biased.

12. It is unclear whether fighting of imported inflation after a devaluation is necessary or inflation will curtail itself because the purchasing power has decreased by the devaluation. 13. Singapore, Taiwan and Hongkong will continue the 'miracle'. Korea, Thailand and Indonesia may undergo a difficult period if not a lost decade.

\section{Appendix}

Some more data of the crisis

summer 1997 spreads of 14 emerging market economies are no higher than 1 percent above US government bonds.

2 july 1997 devaluation of Thai baht; capital flight from Thailand and Malaysia.

Dec 1997 capital flight fromAsia, dollar up. The won has a low at 2000 won per \$. By mid-december more than $\$ 1$ billion a day was flowing out of Korea.

Dec 18 Korean foreign-exchange reserves had fallen to less than $\$ 10$ billion. Default was 10 days away. Japanese stock markets dipped 10\% and the Dow Jones 100 points.

Dec 211997 Mussa defends IMF by arguing that it has warned rather often against bubble economies, unclear banking practices and risky speculation. As long as people believe that money flows into these countries it will flow in and vice versa .

Dec 231997 Seoul stock exchanges looses 7,5\%, interest on 3 years obligations is 31\%; Japanese banks have already decided to prolongate Korean loans; other banks inofficially announce to do the same. Standard and Poor's characterizes Korean foreign debt as 'junk bonds' (repayment is doubtful). Moody's gave a similar rating earlier. Korean debt is estimated to be $\$ 200-250$ bil..

Dec 291997 Korea announces comprehensive reforms of the financial sector. The won increases by $7 \%$. Korea's unemployment rate goes from 2,1 to $2,6 \%$.

The Japanese stock exchange has a 'low of the year'.

Thai banks announce to have made twice as much profit from foreign exchange trading than in the year before.

Dec 1997 Japan premium one procent, but less in jan 1998.

Dec 301997 Commercial banks intend to give Korea an additional \$10 billion in the form of renewing short term credit contracts for 1,5 years.

$1998 \quad$ Japanese government provides fl. 250bn. for banks.

Jan 1 Kim Dae Jung predicts Korea to need two years to solve the debt crisis.

Jan 151998 Soharto promises to give up friendship and family monopolies vis-a-vis IMF.

Jan 161998 Standard and Poors sets rating of Korea from 'negative 'to 'developing'

Jan 17

jan 20

26 jan, Tokio stock exchange goes up again

Jan 26 dollar down, Lewinski/Clinton, money back to Asia?

Jan 291998 Korean short debt of \$24 billion are rescheduled towards later repayment data; intererst becomes LIBOR $+2,25-2,75 \%$ for these loans. IMF pays $\$ 8$ billion. Citibank, Bank of America, Chase Manhattan, JP Morgan, Bank of Nova Scotia, HSBC Holdings, SBC Warburg-Dillon Read, Bank of TokyoMitsubishi, Sanwa Bank, Deutsche Bank, Commerzbank, Westdeutsche Landesban, Société General. 
Jan30 1998 Indonesia expects two million mor unemployed for 1998 plus two million school leavers who have rather low probabilities to find a job.

Alan Greenspan estimates the losses for international investors as hihg as $\$ 700$ billion dollars.

Thailand wants $\$ 600$ million from the IMF to alleviate social problems.

Feb 21998 Standard and Poor's estimates that European banks may loose up to \$20 billion of their loans in the Asian region. Profits before taxes could decrease by $75 \%$.

Deutsche Bank increases it reserves by $\$ 1,4$ billion. In Indonesia there are riots because of price increases on food, and burning materials (kerosine).

Feb 41998 The US governement invites 21 Asian countries for a conference on the future prevention of economic crises. The IMF pays $\$ 2,8$ billion to Argentina's reserves for potential problems.

Feb 91998 Indonesian government unions expect to have 12,5 million unemployed of a working population of 90 million by end of 1998 .

Feb 16 The Vietnamese dong is going down by $5 \%$.

\section{References}

Boonstra, W.W. and Y.M.J. Möller (1998), Crisis in Azië en de wereldeconomie, Economisch-Statistische Berichten, 16-1-1998, 42-44.

Calvo, G.A., Leiderman, L. And C.M. Reinhart (1990), The Capital Inflows Problem:

Concepts and Issues, Contemporary Economic Policy, 12(3), July, 54-66.

Collins, Susan M. And Barry Bosworth (1996), Economic Growth in East Asia:

Accumulation versus Assimilation, Brookings papers on Economic Activity, 2: 1996, 135-

203.

Doukas, J. (1989), Contagion Effect on Sovereign Interest Rate Spreads, Economics Letters 29, 237-241.

Eichengreen, B. A.Rose and C. Wyplosz (1996), Contagious currency Crises: First Tests. Fischer, Stanley (1998), The Asian Crisis: A View from the IMF, Address at the Midwinter Conference of the Bankers' Association for Foreign Trade, Washington D.C. January 22. Greenspan, Alan (1997, 1998), Testimony of Chairman Alan Greenspan, Before the Commitee on Banking and Financial Services, U.S. House of Representatives, November 13, 1997, and january 30, 1998.

Krugman, Paul R., (1979), a model of balance of payments crises, Journal of Money, Credit and Banking 11: 311-325.

, (1997a), What ever happened to the Asian miracle? Mimeo. , (1997b), Currency crises, paper prepared for an NBER conference,

november. , (1997c) Bahtulism, Slate, August 14. , (1998a), What happened to Asia?, mimeo, January. , (1998b), Fire-Sale FDI, mimeo, february. , (1998c), Asia: What went wrong, Fortune March 2.

Litan, Robert E. (1998), A ThreeStep Remedy For Asia's Financial Flu, Brooking Policy Brief Series.

Noland, Marcus, (1998), The financial crisis in Asia, Statement before the House Internatinal Relations Committee Subcommittees on Asian and Pacific Affairs, and International Economic Policy, February 4. 
Obstfeld, Maurice (1994) The logic of curency crisis, Cahiers Economiques et Monetaires 43: 189-213.

Sachs, J. (1981), the Current Account and Macroeconomic Adjustment in the 1970s, Brookings Papers on Economic Activity, 1, 201-282.

Solomon, R. (1977), A Perspective on the Debt of Developing Countries, Brookings Papers on Economic Activity, 2, 479-501, with comments by Greenspan, Kareken and Solow. Ruyter van Stevenick, Thijs de, (1998), Burenruzie om Oost-Azië, Economisch-Statistische Berichten, 16-1-1998, p.25.

Todaro, Michael P. (1994), Economic Development, 5th edition, Longman, New York and London.

Young, Alwyn (1994), Lessons from the East Asian NICs: A Contrarian View, European Economic Review, May.

Ziesemer, Thomas (1997a), Ursachen von Verschuldungskrisen, Metropolis-Verlag, Marburg.

(1997b), From loan Pushing to Credit Rationing: A Brief Note on Interest Shocks in a Model by Basu, Journal of Institutional and Theoretical Economics, Vol. 153, No.3, September, 569-78.

(1998), A Prebisch-Singer Growth Model and the Debt Crises,

Macmillan. 
$\ln \mathrm{y}$

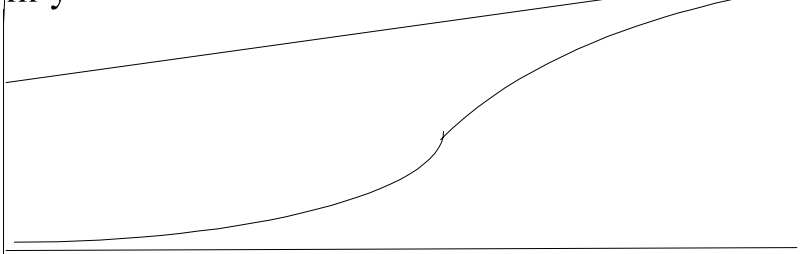

Figure 1: Transition from a steady state with a low growth rate of GDP per capita to a steady state with a high growth rate. 


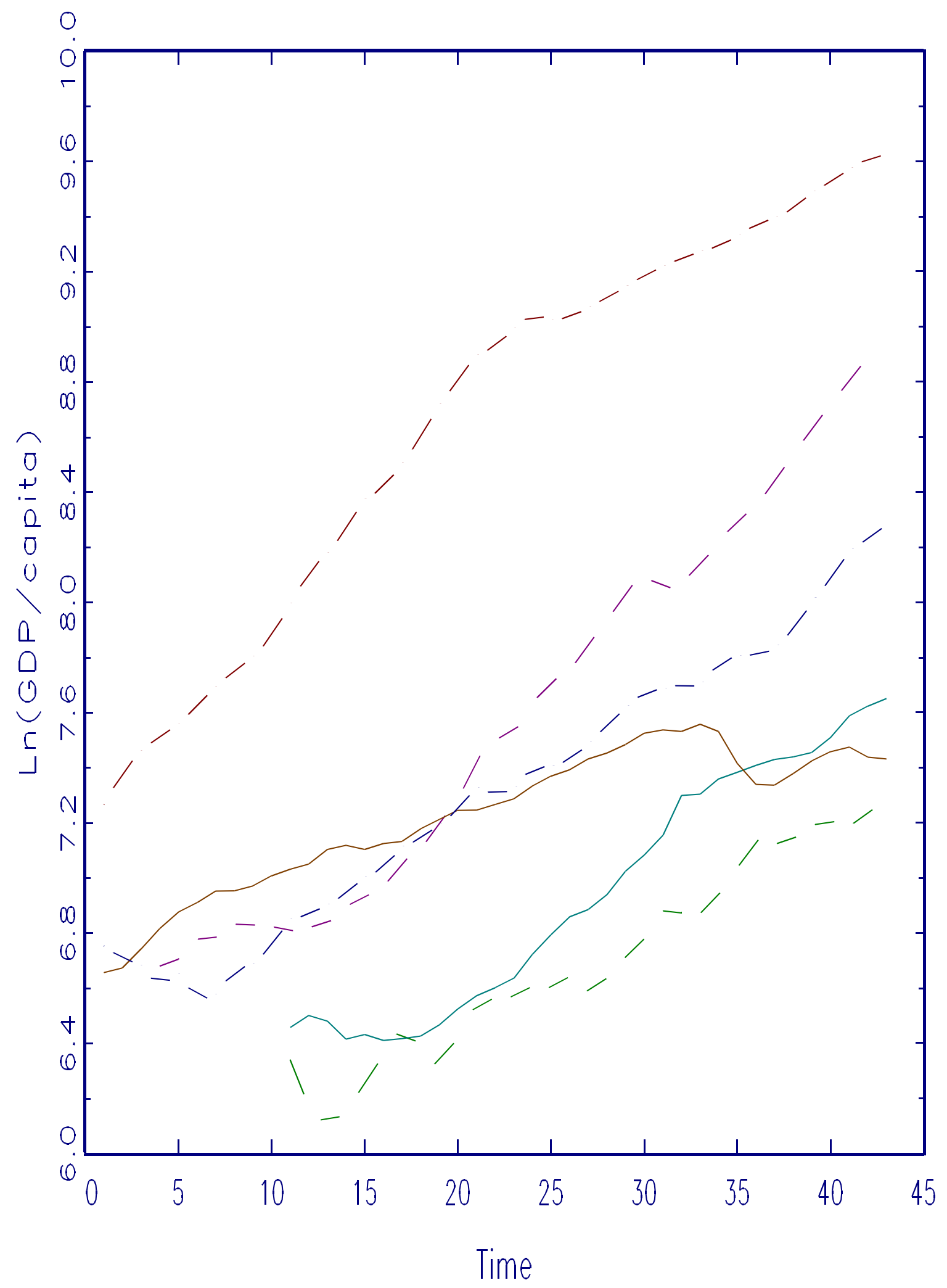

Figure 2: The lines represent the ln GDP of the following countries (from above at the end of the lines): Japan, Korea, Thailand, Indonesia, Phillipines, China. 


\section{Endnotes}

1. Information details that are presented without any source are taken from the business press: The Economist, Time Magazine, deVolkskrant, DieZeit. I am grateful to Karen Kamp and Bart Verspagen for the provision of very helpful information.

2.Sachs view has been expressed in a series of newspaper articles: "Personal view: Jeff Sachs" in Financial Times, July 30, 1997; "The wrong medicine for Asia" in New York Times November 3, 1997; "IMF is a power unto itself" in Financial Times December 11,1997.

3.Except for the causality going from the plunge of the stock exchange and land prices to devaluation, what Krugman (1998a) tells is a view also expressed by D. McDermott and D. Wessel, FinancialSector Weaknesses Are Roiling Asian Currencies, The Wall Street Journal, October 6, 1997. Also Noland (1998) sounds rather similar to Krugman's argument. However, he does not see moral hazard as a cause of asset bubbles.

4. This is based on Joseph Stiglitz, Bad Private-Sector Decisions, Wall Street Journal, February 4, 1998.

5.This paragraph is based on information from Theo Sommer. Das entzauberte Modell, Die Zeit, Nr.1, 26.December 1997 and other articles of the busines press, mainly The Economist.

6.This para is based on 'Taking a baht / Thailand's currency troubles' The Economist, Feb 22 1997 and other articles from the Economist as well as Chronology of the Asian Currency Crisis and its Global Contagion.

7.See the interview with David Crocket in DieZeit Nr.5, 22. January 1998.

8.Parts of this paragraph are based on Petra Pinzler, Problem vertagt, DieZeit, Nr.343, 17. October 1997

9.Answer to Jim Lehrer in "Correcting the Crisis", January 12, 1998, The NewsHour with Jim Lehrer Transcript in 'Online focus', Online Newshour. 